\title{
PENERAPAN PERENCANAAN PAJAK PENGHASILAN PADA FA TRICO PAINT FACTORY
}

\author{
Stefanus Ariyanto; Andrew Hartanto \\ Jurusan Akuntansi, Fakultas Ekonomi dan Bisnis, Bina Nusantara University \\ Jln. K.H. Syahdan No. 9, Kemanggisan, Palmerah, Jakarta Barat 11480
}

\begin{abstract}
The most important parts of government income comes from taxes, especially income taxes. The different point of view arises between government and tax payer. While the government try to increase the tax income, the taxpayers always intend to minimize their tax burden by implementing tax management/plannning. This paper is a case study in FA Trico Paint Factory (FA TPF) that try to reperforming company's income tax return preparation with the main purpose to minimize company tax burden, while it is still comply with tax regulations in Indonesia. This approach could be an alternative for the company to restate it's annual income tax return, to avoic fines and charges for not comply with the regulations, and minimize it's income tax expense by approximately $10 \%$ per year.
\end{abstract}

Keywords: income tax, tax management, tax planning

\begin{abstract}
ABSTRAK
Pajak merupakan salah satu komponen terbesar dalam penerimaan negara. Di lain pihak terdapat perbedaan kepentingan dengan Wajib Pajak yang selalu berusaha membayar pajaknya seminimal mungkin. Oleh sebab itu Wajib Pajak dalam menjalankan usahanya memerlukan suatu perencanaan pajak yang didasarkan pada peraturan perpajakan yang berlaku. Penelitian yang dilakukan pada FA Trico Paint Factory (FA TPF) adalah jenis penelitian kualitatif, yang menggunakan metode penelitian lapangan dan penelitian kepustakaan. Penelitian lapangan dilakukan dengan menganalisa data laporan keuangan dan SPT perusahaan dan melakukan perhitungan ulang pajak terhutang. Sedangkan untuk penelitian kepustakaan dilakukan dengan membandingkan data-data perpajakan perusahaan dengan teori dan peraturan pajak yang berlaku. Hasil penelitian yang dilakukan menunjukan bahwa FA. TPF belum melakukan perencanaan pajak secara tepat. Hal itu ditunjukan dengan masih banyaknya koreksi fiskal positif dan negatif yang dilakukan. TPF dapat menghasilkan penghematan PPh Badan rata-rata 10\% per tahun.
\end{abstract}

Kata kunci: perencanaan pajak, koreksi positif, koreksi negatif 


\section{PENDAHULUAN}

Salah satu komponen penerimaan negara non migas yang utama adalah dari sektor pajak. Pajak merupakan unsur utama dalam pendanaan pembangunan infrastruktur suatu negara, khususnya di Indonesia. Berbagai upaya formal dilakukan oleh pemerintah, yaitu dengan melakukan amandemen Undang-Undang Perpajakan secara berkesinambungan. Di mana semuanya itu bertujuan untuk memperluas penerimaan pajak dari berbagai sektor. Salah satu perubahan mendasar yang dilakukan oleh Undang-undang Perpajakan adalah diterbitkannya Undang-Undang Nomor 36 Tahun 2008 tentang Pajak Penghasilan yang berlaku mulai tahun 2009. Undang-undang yang baru tersebut merupakan perubahan keempat sebagaimana telah diubah terakhir pada Undang-Undang Nomor 17 Tahun 2000. Pada Undang-Undang Pajak Penghasilan yang baru tersebut, terjadi perubahan tarif umum Pajak Penghasilan yang diatur dalam Pasal 17. Baik tarif untuk Wajib Pajak Orang Pribadi maupun Wajib Pajak Badan, kedua-duanya mengalami perubahan. Namun demikian, sifat perubahannya berbeda. Apabila tarif PPh Orang Pribadi hanya berubah dalam hal tarif dan lapisan kena pajaknya, perubahan tarif PPh badan lebih ke jenis tarifnya yaitu dari tarif progresif menjadi tarif tunggal (single tax).

Sejak tahun 2009, tarif PPh Badan menganut sistem tarif tunggal yaitu 28\% dan akan menjadi 25\% pada tahun 2010. Jadi berapapun penghasilan kena pajaknya, tarif yang dikenakan adalah sama. Secara umum, perubahan tarif PPh Badan ini menguntungkan bagi perusahaan-perusahaan besar yang biasanya terkena tarif lapisan tertinggi 30\%. Namun bagi perusahaan-perusahaan kecil dan menengah, yang biasanya terkena tarif dengan lapisan kena pajak rendah tentu saja akan merugikan karena akan mengalami kenaikan tarif. Namun demikian, ada ketentuan baru dalam Pasal 31E Undang-Undang PPh yang memberikan fasilitas pengurangan tarif sebesar 50\% dari tarif umum untuk Wajib Pajak Badan yang peredaran brutonya tidak melebihi Rp. 50 Milyar dan penghasilan kena pajaknya sampai dengan Rp. 4,8 Milyar.

Di lain pihak, masyarakat dalam hal ini Wajib Pajak memiliki kepentingan yang berbeda dalam pemenuhan kewajiban perpajakan. Wajib Pajak selalu berusaha untuk membayar pajak dalam jumlah yangpaling minimum. Setiap Perusahaan baik yang bergerak dibidang jasa, perdagangan, dan manufaktur selalu berupaya untuk meminimalkan biayaagar tetap dapat mempertahankan daya saingnya. Oleh karena itu, pajak yang dianggap oleh perusahaan juga sebagai biaya harus diminimalkan pembayarannya. Agar dapat memenuhi kewajiban perpajakan dengan baik dan meminimalkan beban pajak yang harus ditanggung oleh Wajib Pajak (khususnya Wajib Pajak Badan), maka pemenuhan kewajiban tersebut harus direncanakan dengan baik melalui suatu perencanaan pajak (tax planning).

Perencanaan pajak (tax planning) adalah bagian dari fungsi manajemen pajak yang merupakan suatu proses pengumpulan dan penelitian terhadap peraturan perpajakan dengan tujuan melakukan penghematan dan penghindaran pajak secara legal (tax avoidance). Perencanaan pajak dilakukan dengan memanfaatkan celah-celah atau kelemahan-kelemahan yang terdapat dalam undang-undang perpajakan yang berlaku tanpa melanggar undang-undang tersebut. Hal itu dilakukan supaya beban pajak yang harus dibayar oleh Wajib Pajak bisa ditekan serendah mungkin. Dalam sistem pemungutan pajak penghasilan di Indonesia, dikenal adanya suatu pendekatan perpajakan, yaitu self assessment system. Sistem ini memberi kepercayaan kepada Wajib Pajak untuk menghitung sendiri jumlah pajak yang terutang, pajak yang telah dibayar sendiri atau dipotong oleh pihak ketiga, melunasi kekurangan pajaknya dan melaporkan pemenuhan kewajiban perpajakannya. Sebagai perwujudan sistem pemungutan tersebut, maka perencanaan pajak yang efektif dan efisien dalam menghitung dan melaporkan pajak penghasilan dapat menjadi pilihan yang tepat bagi Wajib Pajak. Perencanaan pajak yang baik dan tepat dapat memberikan hasil yang maksimal bagi laba perusahaan. Namun dari semua perencanaan pajak atas transaksi yang terjadi di suatu perusahaan harus mempertimbangkan berbagai aspek hukum perpajakan yang ada. 
FA TPF merupakan salah satu perusahaan berbentuk persekutuan (firma) yang bergerak di bidang industri pembuatan cat seperti cat besi, tembok, dan kayu. Setiap aktivitas transaksinya memiliki keterkaitan yang erat dengan masalah perpajakan, khususnya pajak penghasilan, sehingga perusahaan tersebut membutuhkan suatu perencanaan pajak yang baik.

Tujuan yang ingin dicapai dalam penelitian ini adalah: (1) untuk menerapkan perencanaan pajak yang tepat dan efektif pada FA TPF; (2) untuk mengevaluasi kepatuhan FA TPF kepada peraturan perundang-undangan pajak untuk menghindarkan sanksi dan/atau denda. Manfaat yang diharapkan dari penelitian ini adalah: (1) dapat memberikan bahan masukan atau rekomendasi yang penting dalam upaya melakukan perencanaan pajak, serta memberikan bahan pertimbangan untuk menentukan bagaimana perusahaan dapat melakukan perencanaan pajak dengan tetap memperhatikan rambu-rambu peraturan perundang-undangan di bidang perpajakan; (2) dapat memberikan wawasan, pengetahuan, dan pemahaman tentang pendekatan perencanaan pajak yang tidak hanya memperhatikan penghematan yang diperoleh perusahaan, namun juga memperhatikan pemenuhan kewajiban perpajakan; (3) dapat memberikan wawasan dan pengetahuan kepada pihak-pihak yang tertarik dengan penelitian ini, serta dapat memberikan informasi bagi mereka yang berminat menelaah lebih lanjut.

\section{METODE PENELITIAN}

Dalam melakukan analisis, pendekatan yang juga digunakan untuk mengumpulkan data-data yang dibutuhkan adalah Metode Pengumpulan Data. Metode ini dilakukan dengan dua cara yaitu studi literatur dan studi lapangan.

\section{Studi Literatur}

Studi untuk memperoleh informasi secara teoritis. Penelitian ini dilakukan melalui pengumpulan data dengan cara membaca dan mempelajari buku-buku, literatur-literatur, dan undangundang yang sesuai dengan topik pembahasan.

\section{Studi Lapangan}

Melakukan penelitian secara langsung pada objek pembahasan yang dilakukan melalui tiga tahap, yaitu survei, analisis hasil survei dan identifikasi kebutuhan informasi. Kegiatan survei dilakukan dengan cara-cara, yaitu: (1) wawancara, dilakukan dengan cara menanyakan langsung kepada para staff maupun pimpinan perusahaan atas informasi yang berkaitan dengan penelitian; (2) pengamatan, dilakukan dengan cara mengobservasi kegiatan-kegiatan atau aktivitas rutin Perusahaan yang berhubungan dengan topik penelitian skripsi; (3) dokumentasi, dilakukan dengan cara menelusuri dan mempelajari dokumen-dokumen yang berkaitan dengan pelaporan pajak penghasilan pada perusahaan. Setelah melakukan kegiatan survei pada Perusahaan, langkah selanjutnya adalah dengan menganalisis hasil survei dengan berdasarkan pendekatan kegiatan penelaahan dan kajian teori-teori yang ada pada literatur yang telah dikumpulkan. Dari hasil analisis yang telah ditemukan, informasi yang ada kemudian diidentifikasikan sesuai dengan kebutuhan yang akan dipergunakan dalam penyusunan skripsi.

\section{HASIL DAN PEMBAHASAN}

Perusahaan Nakami Kinema Cemerlang didirikan pada awal tahun 1966, dan memilih menggunakan bentuk badan hukum firma, yang dimiliki oleh 5 sekutu utama, dimana sekutu aktif yang terlibat dalam manajemen perusahaan adalah sebanyak 3 orang. Produk utama dari perusahaan ini adalah cat minyak. Untuk menghitung besarnya penghasilan kena pajak, FA. TPF telah menyusun 
laporan keuangan yang terdiri dari neraca dan laporan laba/rugi. Perusahaan menyusun laporan keuangan tersebut sesuai dengan prinsip akuntansi yang berlaku umum. Perusahaan tidak membedakan antara laporan keuangan yang disusun untuk kepentingan komersial juga merupakan laporan keuangan yang menjadi lampiran Surat Pemberitahuan Tahunan (SPT) PPh Badan, karena pengetahuan yang terbatas mengenai perpajakan dan akuntansi pajak. Perusahaan juga belum pernah mengalami pemeriksaan pajak. Karena kondisi tersebut penulis melakukan dua langkah perencanaan pajak yaitu mencari posisi pajak terhutang yang paling wajar dengan melakukan koreksi fiskal atas laporan keuangan komersial perusahaan, dilanjutkan dengan langkah kedua berupa perencanaan pajak.

Tabel 1 merupakan laporan keuangan komersial sekaligus fiskal dari perusahaan, yang terdiri dari Neraca dan Laporan Laba Rugi tahun 2007, 2008, dan 2009.

Tabel 1 Laporan Keuangan Komersial dan Fiskal Perusahaan

$$
\begin{aligned}
& \text { FA. TPF } \\
& \text { NERACA }
\end{aligned}
$$

PER, 31 DESEMBER 2007

\begin{tabular}{|c|c|}
\hline AKTIVA & \\
\hline AKTIVA LANCAR : & \\
\hline Kas & $100,820,625.00$ \\
\hline $\begin{array}{l}\text { Bank Bca ( Reconsiliasi) } \\
\text { Piutang Dagang }\end{array}$ & $\begin{array}{l}1,503,154,738.29 \\
4,106,677,932.00\end{array}$ \\
\hline Persediaan & $\underline{3,182,595,632.80}$ \\
\hline JUMLAH AKTIVA LANCAR & $\underline{8,893,248,928.09}$ \\
\hline $\begin{array}{l}\text { AKTIVA TETAP : } \\
\text { Aktiva Tetap (Nilai Buku) }\end{array}$ & $\underline{4,181,929,906.50}$ \\
\hline JUMLAH AKTIVA TETAP & $\underline{4,181,929,906.50}$ \\
\hline TOTAL AKTIVA & $13,075,178,835.00$ \\
\hline HUTANG LANCAR : & \\
\hline Hutang Dagang & $8,701,692,243.00$ \\
\hline Hutang PPN & $34,133,008.00$ \\
\hline Hutang PPh 21 & $5,227,300.00$ \\
\hline Hutang PPh 25 & $13,601,700.00$ \\
\hline Hutang SPT PPh 21 & $2,872,370.00$ \\
\hline Hutang SPT PPh 25 & $36,625,900.00$ \\
\hline Hutang Pajak Psl 29 Tahun (2001 - 2007) & $\underline{198,879,845.00}$ \\
\hline JUMLAH HUTANG LANCAR & $\underline{8,993,032,366.00}$ \\
\hline MODAL : & \\
\hline Modal Yang Disetor & 3,553,340,586.00 \\
\hline Laba Tahun Berjalan & $\underline{528,805,883.00}$ \\
\hline JUMLAH MODAL & $\underline{4,082,146,469.00}$ \\
\hline TOTAL HUTANG \& & 13,075,178,835.00 \\
\hline
\end{tabular}

(Dalam Rupiah Penuh) 
Tabel 2 Laporan laba rugi perusahaan

FA. TPF

LAPORAN LABA RUGI

PERIODE YANG BERAKHIR 31 DESEMBER 2007

(Dalam Rupiah Penuh)

\begin{tabular}{lr}
\hline PENDAPATAN & \\
Penjualan Bersih & $39,857,946,635.00$ \\
HARGA POKOK PENJUALAN & $(37,280,216,314.00)$ \\
LABA KOTOR & $\mathbf{2 , 5 7 7 , 7 3 0 , 3 2 1 . 0 0}$ \\
BIAYA OPERASIONAL \& PEMASARAN & $\underline{(2,029,965,994.00)}$ \\
LABA OPERASIONAL & $\mathbf{5 4 7 , 7 6 4 , 3 2 7 . 0 0}$ \\
PENDAPATAN \& BIAYA LAIN - LAIN & $252,881,564.00$ \\
Pendapatan Lain - Lain & $\underline{(38,561,009.00)}$ \\
Biaya Lain - Lain & $\underline{\mathbf{2 1 4 , 3 2 0 , 5 5 5 . 0 0}}$ \\
Jumlah Pendapatan \& Biaya Lain -Lain & $\mathbf{7 6 2 , 0 8 4 , 8 8 2 . 0 0}$ \\
LABA SEBELUM PAJAK & $(233,279,000.00)$ \\
PPh Psl 25 / 2007 & $\mathbf{5 2 8 , 8 0 5 , 8 8 2 . 0 0}$ \\
\hline LABA SETELAH PAJAK
\end{tabular}

Sumber: Data primer dari perusahaan, laporan keuangan 2007

Tabel 3 Neraca perusahaan

FA. TPF

NERACA

PER, 31 DESEMBER 2008

(Dalam Rupiah Penuh)

AKTIVA

AKTIVA LANCAR :

Kas

$159,628,486.00$

Bank BCA (Reconciled)

$7,325,953,873.55$

Piutang Dagang

$11,155,056,002.70$

Persediaan

$\underline{4,539,970,776.29}$

JUMLAH AKTIVA LANCAR

$\underline{23,180,609,138.55}$

AKTIVA TETAP :

Aktiva Tetap (Nilai Buku)

$\underline{5,304,181,198.69}$

JUMLAH AKTIVA TETAP

$5,304,181,198.69$

TOTAL AKTIVA

28,484,790,337.00 
Tabel 3 Neraca perusahaan (lanjutan)

$$
\text { FA. TPF }
$$

NERACA

PER, 31 DESEMBER 2008

(Dalam Rupiah Penuh)

\begin{tabular}{lr}
\hline HUTANG \& MODAL & \\
HUTANG LANCAR : & \\
Hutang Dagang & $8,812,551,284.00$ \\
Hutang Persero & $14,800,000,000.00$ \\
Hutang PPN & $78,956,317.00$ \\
Hutang PPh 21 & $5,232,600.00$ \\
Hutang PPh 25 & $44,574,000.00$ \\
Hutang SPT PPh 21 & $55,330,300.00$ \\
Hutang SPT PPh 25 & $\mathbf{4 7 , 8 6 1 , 9 0 0 . 0 0}$ \\
JUMLAH HUTANG LANCAR & $\underline{\mathbf{2 3 , 8 4 4 , 5 0 6 , 4 0 1 . 0 0}}$ \\
MODAL : & \\
Modal Yang Disetor & $\mathbf{4 , 0 8 2 , 1 4 6 , 4 6 8 . 5 9}$ \\
Laba Tahun Berjalan & $\underline{\mathbf{5 5 8 , 1 3 7 , 4 6 8 . 0 0}}$ \\
JUMLAH MODAL & $\mathbf{4 , 6 4 0 , 2 8 3 , 9 3 6 . 5 9}$ \\
\hline TOTAL HUTANG \& MODAL & $\mathbf{2 8 , 4 8 4 , 7 9 0 , 3 3 7 . 0 0}$ \\
\hline
\end{tabular}

FA. TPF

LAPORAN LABA RUGI

PERIODE YANG BERAKHIR 31 DESEMBER 2008

(Dalam Rupiah Penuh)

\section{PENDAPATAN}

Penjualan Bersih

$46,468,964,837.00$

HARGA POKOK PENJUALAN

$(43,064,821,026.00)$

\section{LABA KOTOR}

$3,404,143,811.00$

BIAYA OPERASIONAL \& PEMASARAN

$(2,695,525,239.00)$

LABA OPERASIONAL

708,618,572.00

PENDAPATAN \& BIAYA LAIN - LAIN

Pendapatan Lain - Lain

$131,278,435.41$

Biaya Lain - Lain

$\underline{(47,800,439.65)}$

Jumlah Pendapatan \& Biaya Lain -Lain

$\underline{83,477,995.76}$

LABA SEBELUM PAJAK

$792,096,567.76$

PPh Psl 25 / 2008

$(233,959,100.00)$

\section{LABA SETELAH PAJAK}

Sumber: Data Primer, Laporan Keuangan FA. TPF Tahun 2008 
Tabel 4 Neraca perusahaan

FA. TPF

NERACA

PER, 31 DESEMBER 2009

(Dalam Rupiah Penuh)

\begin{tabular}{|c|c|}
\hline AKTIVA & \\
\hline AKTIVA LANCAR : & \\
\hline Kas dan Bank & $5,229,737,966.00$ \\
\hline Piutang Dagang & $10,317,126,990.00$ \\
\hline Persediaan & $4,715,284,980.00$ \\
\hline Uang Muka PPN & $189,812,441.00$ \\
\hline JUMLAH AKTIVA LANCAR & $\underline{20,451,962,377.00}$ \\
\hline AKTIVA TETAP : & \\
\hline Aktiva Tetap (Nilai Buku) & $\underline{6,120,207,112.00}$ \\
\hline JUMLAH AKTIVA TETAP & $\underline{6,120,207,112.00}$ \\
\hline TOTAL AKTIVA & $\underline{26,572,169,489.00}$ \\
\hline HUTANG \& MODAL & \\
\hline HUTANG LANCAR : & \\
\hline Hutang Dagang & $5,937,948,862.00$ \\
\hline Hutang Pajak & $180,340,626.00$ \\
\hline Hutang Potongan dan Pungutan & $100,000.00$ \\
\hline Hutang Sekutu & $6,645,205,747.00$ \\
\hline JUMLAH HUTANG LANCAR & $\underline{12,763,595,235.00}$ \\
\hline MODAL : & \\
\hline Modal Yang Disetor & $13,114,283,937.00$ \\
\hline Laba Tahun Berjalan & $694,290,315.00$ \\
\hline JUMLAH MODAL & $\underline{13,808,574,252.00}$ \\
\hline TOTAL HUTANG \& MODAL & $\underline{26,572,169,489.00}$ \\
\hline
\end{tabular}


Tabel 5 Laporan laba rugi perusahaan

FA. TPF

LAPORAN LABA RUGI

PERIODE YANG BERAKHIR 31 DESEMBER 2009

(Dalam Rupiah Penuh)

PENDAPATAN

Penjualan Bersih

HARGA POKOK PENJUALAN

LABA KOTOR

BIAYA OPERASIONAL \& PEMASARAN

LABA OPERASIONAL

PENDAPATAN \& BIAYA LAIN - LAIN

Pendapatan Lain - Lain

Biaya Lain - Lain

Jumlah Pendapatan \& Biaya Lain -Lain

LABA SEBELUM PAJAK

PPh Psl 25 / 2009

LABA SETELAH PAJAK
$39,851,765,010.00$

$(35,863,896,146.00)$

$3,987,868,864.00$

$(3,046,169,028.00)$

$941,699,836.00$

$143,213,628.00$

$\underline{(104,548,376.00)}$

$\underline{38,665,252.00}$

$980,365,088.00$

$(286,074,773.00)$

$694,290,315.00$

Sumber: Laporan Keuangan FA. TPF Tahun 2009

\section{Analisis Terhadap Biaya dalam Laporan Laba Rugi Perusahaan yang Memiliki Potensi Pajak Tahun 2007-2009}

Perusahaan mengeluarkan biaya-biaya operasional secara umum selama tahun 2007-2009 untuk menjalankan usahanya. Sebelum melakukan koreksi fiskal atas laporan laba rugi perusahaan maka perlu dilakukan analisis atas biaya-biaya tersebut dan dampak pajaknya. Biaya-biaya operasional tersebut adalah: (1) perusahaan mengeluarkan biaya gaji dan THR kepada karyawannya. Gaji tersebut diberikan kepada karyawannya berdasarkan golongan, dan THR diberikan kepada karyawan dan buruhnya sekali dalam setahun. Perusahaan menanggung biaya angsuran PPh pasal 21 atas untuk karyawannya. (2) Perusahaan menggunakan jasa pihak ketiga seperti jasa pemeliharaan dan notaris dalam melakukan pemeliharaan atau perawatan asset serta pengurusan perizinan. (3) Perusahaan mengeluarkan biaya sumbangan dalam rangka membantu kegiatan-kegiatan sosial seperti pembangunan tempat ibadah, memberikan santunan kepada anak-anak di panti asuhan dan orangorang yang lanjut usia di panti jompo yang berada di sekitar Jakarta utara. (4) Biaya bahan bakar, parkir, dan tol dikeluarkan oleh perusahaan sehubungan dengan operasi perusahaan, seperti membeli bahan baku produksi dan mengantar pesanan barang dagangan kepada pelanggan. (5) Biaya perjalanan merupakan perjalanan dinas perusahaan ke luar kota yang dilakukan oleh Manajer pemasaran untuk menjalin hubungan dengan toko-toko material besar yang mengambil produk cat dari Perusahaan dan juga dalam rangka memasarkan produk serta mengantarkan barang kepada pelanggan. (6) Perusahaan menanggung pengisian pulsa handphone sebesar Rp. 600.000,00 setiap bulannya untuk 3 orang sekutu pemimpin firma. Di mana pemberian natura tersebut dibiayakan pada pos biaya telepon perusahaan yang juga digunakan untuk operasional perusahaan. (7) Biaya iklan dikeluarkan perusahaan untuk 
mempromosikan produk-produknya kepada pelanggan, seperti mencetak spanduk yang diberikan ke toko-toko material yang menjual produk, iklan di surat kabar, dan mencetak katalog jenis dan warna cat untuk toko-toko material demi mempermudah penjelasan kepada pelanggan. (8) Perusahaan mengeluarkan biaya representasi tamu untuk menjamu pelanggan dan kolega bisnis. (9) Perusahaan membayar biaya listrik dan PAM yang digunakan untuk kegiatan operasional perusahaan. (10) Perusahaan mengeluarkan biaya perlengkapan kantor yang digunakan untuk membeli alat tulis kantor, kertas fotokopi, tinta fotokopi, tinta printer, dan perlengkapan kantor lainnya untuk menunjang kegiatan operasional kantor. (11) Biaya pengobatan kantor dan pengobatan buruh dikeluarkan perusahaan untuk menanggung biaya pengobatan karyawan yang sakit ringan maupun yang dirawat di rumah sakit. (12) Biaya surat kabar dikeluarkan perusahaan untuk membayar langganan koran dan majalah untuk keperluan kantor. (13) Biaya penyusutan kendaraan dihitung berdasarkan penyusutan aktiva kelompok II. Perusahaan menggunakan metode saldo menurun dengan masa manfaat 5 tahun.

\section{Koreksi Fiskal yang Dilakukan Penulis Tahun 2007-2009 sebelum Perencanaan Pajak}

\section{Tahun 2007}

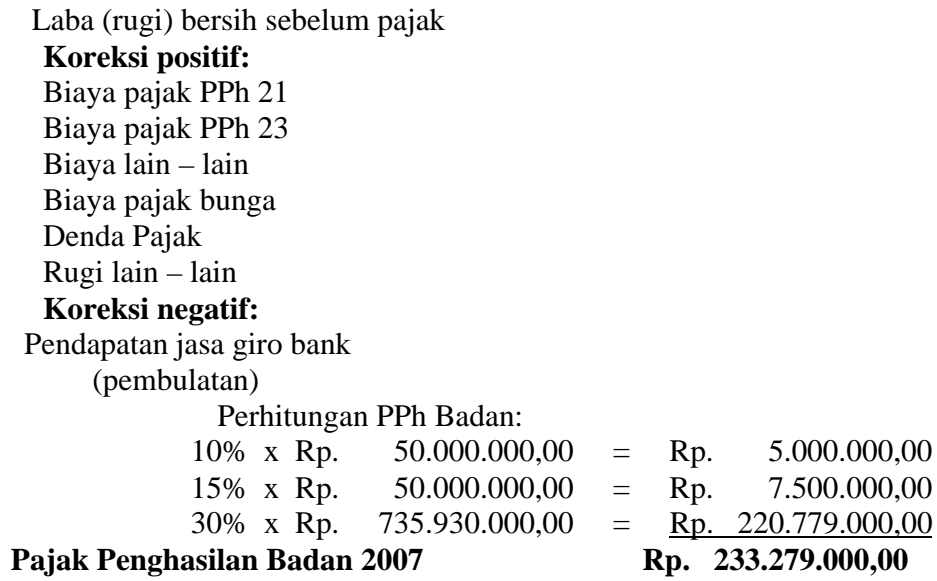

\section{Tahun 2008}

Rp. $762.084 .882,00$

Rp. $61.031 .200,00$

Rp. 77.000.000,00

Rp. $\quad 54.351,00$

Rp. 18.576.313,00

Rp. $\quad 5.325 .523,00$

Rp. $\quad 4.739 .973,00$

Rp. 92.881.654,00) Laba kena pajak Rp. 835.930.000,00 $\begin{array}{lr}\text { Rp. } & 118.105 .600,00 \\ \text { Rp. } & 18.737 .890,00 \\ \text { Rp. } & 4.260 .000,00 \\ \text { Rp. } & 22.759 .855,00 \\ \text { Rp. } & 13.516 .289,00 \\ & \\ \text { Rp. } & (17.085 .512,00) \\ \text { Rp. }(114.192 .923,00) \\ \text { Rp. } 838.197 .000,00\end{array}$ 


\section{Tahun 2009}

Laba (rugi) bersih sebelum pajak Rp. 980.365.084,00 Koreksi positif:

Biaya pajak PPh 21

Rp. $87.359 .750,00$

Biaya entertainment

Rp. 25.434.500,00

Biaya pajak bunga

Rp. 28.615.097,00

Denda Pajak

Rp. 28.338.708,00

Koreksi negatif:

Pendapatan jasa giro bank

Rp.(143.075.484,00)Laba kena pajak (pembulatan)

Rp. 978.422.561,00_Perhitungan PPh

Badan:

Penghasilan Kena Pajak

Fasilitas = Rp. 4,8 Milyar / Rp. 39.851.765.010,00 x Rp. 978.422.561,00

$=$ Rp. 117.847.435,00

Non Fasilitas = Rp. 978.422.561,00 - Rp. 117.847.435,00

PPh Terhutang:

$=$ Rp. 860.575.126,00

$14 \%$ x Rp. $117.847 .435,00=$ Rp. $16.498 .641,00$

$28 \% \mathrm{x} \quad$ Rp. $860.575 .126,00=$ Rp. $240.961 .035,00$

Rp. $\quad 257.459 .676,00$

\section{Detail Koreksi Fiskal yang Dilakukan Penulis Tahun 2007-2009 sebelum Perencanaan Pajak}

\section{Biaya Gaji Pegawai}

Perusahaan harus melakukan koreksi fiskal positif sebagian terhadap biaya gaji pegawai, hal ini dilakukan karena di dalam biaya gaji pegawai tersebut terdapat biaya gaji yang dibayarkan kepada tiga orang sekutu FA. Trico Paint. Karena menurut UU PPh Pasal 9 ayat 1 (i) yaitu gaji yang dibayarkan kepada anggota persekutuan, firma, atau perseroan komanditer yang modalnya tidak terbagi atas saham tidak dapat dijadikan biaya untuk mengurangi penghasilan bruto. Besarnya koreksi yang dilakukan berasal dari SPT Tahunan PPh 21 perusahaan dengan rincian sebagai berikut:

Tahun 2007:
a. LWT
b. HTA
c. JHK

Tahun 2008:

Total Koreksi

a. Lie Wie Tjung

b. Hioe Tama Adhiputra

c. Jauw Hin Kok

Tahun 2009:
a. Lie Wie Tjung
b. Hioe Tama Adhiputra
c. Jauw Hin Kok

Total Koreksi
Rp. $120.000 .000,00$

Rp. $\quad 96.000 .000,00$

Rp. $\quad 96.000 .000,00$

Rp. $312.000 .000,00$

Rp. $156.000 .000,00$

Rp. 132.000.000,00

Rp. $132.000 .000,00$

Rp. $420.000 .000,00$

Rp. 162.000.000,00

Rp. $138.000 .000,00$

Rp. $138.000 .000,00$

Rp. $438.000 .000,00$

\section{Biaya Telepon}

Perusahaan harus melakukan koreksi positif sebagian terhadap biaya telepon, karena perusahaan menanggung pulsa handphone dari tiga orang anggota sekutunya sebesar Rp. 600.000,00 per bulan. Berdasarkan UU PPh Pasal 9 ayat 1 (b) yaitu biaya yang dibebankan atau dikeluarkan untuk kepentingan pribadi pemegang saham, sekutu, atau anggota tidak dapat dijadikan biaya untuk 
mengurangi penghasilan bruto. Adapun besarnya koreksi setiap tahunnya atas biaya telepon dari tahun 2007-2009 tersebut adalah sebesar Rp. 21.600.000,00 yang didapat dari:

$$
\begin{aligned}
& \text { Rp. 600.000,00/bulan x } 3 \text { orang } \quad=\text { Rp. 1.800.000,00/bulan } \\
& \text { Rp. 1.800.000,00/bulan x } 12 \text { bulan } \quad=\text { Rp. 21.600.000,00 }
\end{aligned}
$$

\section{Biaya Entertaiment}

Perusahaan harus melakukan koreksi fiskal positif atas biaya entertaiment. Karena atas biaya yang dibebankan tersebut tidak didukung oleh bukti-bukti yang memadai terkait dengan biaya tersebut. Dalam hal ini perusahaan tidak membuatkan daftar nominatif atas biaya entertaiment tersebut sehingga biaya-biaya tersebut dianggap fiktif. Berdasarkan SE-27/PJ.22/1986 yang menyatakan biaya entertaiment, representasi, jamuan tamu, dan sejenisnya untuk mendapatkan, menagih, dan memelihara penghasilan yang merupakan obyek PPh dan tidak terkena PPh Final dapat dikurangkan dari penghasilan bruto, dengan syarat dibuatkan daftar nominatif dan dilampirkan dalam SPT Tahunan PPh. Oleh karena itu biaya entertaiment harus dikoreksi adalah sebesar Rp. 43.396.710,00 untuk tahun 2007, Rp. 16.221.233,00 untuk tahun 2008, dan Rp. 25.434.500,00 untuk tahun 2009.

\section{Biaya Penyusutan Kendaraan}

Perusahaan harus melakukan koreksi fiskal atas biaya penyusutan kendaraan. Hal ini harus dilakukan karena perusahaan mengkategorikan kendaraan sebagai aktiva bukan bangunan kelompok II dengan menggunakan metode penyusutan saldo menurun dan menggunakan masa manfaat 5 tahun (40\%). Sedangkan menurut UU PPh Pasal 11 ayat 6 metode penyusutan saldo menurun untuk kategori aktiva bukan bangunan kelompok 2 masa manfaat yang diperkenankan adalah 8 tahun (25\%). Dan untuk penyusutan sepeda motor dinas yang digunakan oleh bagian penjualan yang menurut KEP220/PJ./2002 dan S-163/PJ.42/2003 seharusnya termasuk aktiva kelompok I dikategorikan oleh perusahaan sebagai aktiva kelompok II. Jumlah biaya penyusutan kendaraan yang dikoreksi sebesar:

Tahun 2007:

Biaya penyusutan kendaraan menurut komersial

Biaya penyusutan kendaraan menurut fiskal

Koreksi fiskal positif

Tahun 2008:

Biaya penyusutan kendaraan menurut komersial

Biaya penyusutan kendaraan menurut fiskal

Koreksi fiskal positif

Tahun 2009:

Biaya penyusutan kendaraan menurut komersial

Biaya penyusutan kendaraan menurut fiskal

Koreksi fiskal negatif

\begin{tabular}{lr} 
Rp. $116.080 .000,00$ \\
Rp. $71.197 .917,00$ \\
\hline Rp. $44.882 .083,00$ \\
Rp. $119.648 .000,00$ \\
Rp. $79.382 .813,00$ \\
\hline Rp. $40.265 .188,00$ \\
Rp. $81.578 .667,00$ \\
Rp. $144.742 .839,00$ \\
Rp. $63.164 .172,00$
\end{tabular}

\section{Biaya Pajak PPh 21}

Berdasarkan UU PPh Pasal 9 ayat 1 (h) yaitu mengenai pajak penghasilan yang bukan merupakan pengurang penghasilan bruto. Dalam hal ini perusahaan menanggung PPh 21 karyawannya, maka atas biaya pajak PPh 21 tersebut harus dilakukan koreksi sebesar Rp. 61.031.200,00 untuk tahun 2007, Rp. 118.105.600,00 untuk tahun 2008, dan Rp. 87.359.750,00 untuk tahun 2009.

\section{Biaya Pajak PPh 23}

Pada tahun 2007 perusahaan menggunakan jasa konstruksi untuk melakukan renovasi pabrik. Oleh karena itu perusahaan memotong PPh 23 atas jasa konstruksi dan membiayakan pemotongan PPh 
23 tersebut. Berdasarkan UU PPh Pasal 9 ayat 1 (h) pemotongan PPh 23 tersebut tidak dapat dibiayakan. Besarnya koreksi yang dilakukan untuk tahun 2007 adalah Rp. 77.000.000,00.

\section{Biaya Pengobatan Kantor}

Pada tahun 2008 perusahaan menanggung biaya pengobatan karyawannya yang sakit, baik secara cuma-cuma (langsung ke rumah sakit) maupun dalam bentuk penggantian (reimburse). Biaya ini dianggap oleh perpajakan sebagai natura atau kenikmatan sesuai dengan UU PPh Pasal 9 ayat 1 (e). Sehinggga atas biaya tersebut harus dilakukan koreksi sebesar Rp. 7.889.250,00.

\section{Biaya Sumbangan}

Pada tahun 2008 perusahaan mengeluarkan biaya sumbangan. Atas biaya tersebut perusahaan harus melakukan koreksi positif sebagaimana tercantum dalam UU PPh Pasal 9 ayat 1 (g) yaitu harta yang dihibahkan, bantuan atau sumbangan, dan warisan kecuali zakat atas penghasilan yang nyatanyata dibayarkan oleh wajib pajak orang pribadi pemeluk agama Islam kepada badan amil zakat atau lembaga amil zakat yang dibentuk atau disahkan oleh pemerintah merupakan biaya yang tidak dapat dikurangkan dari penghasilan. Besarnya koreksi yang harus dilakukan oleh perusahaan adalah sebesar Rp. 4.260.000,00.

\section{Biaya Lain-Lain dan Rugi Lain-Lain}

Perusahaan mencantumkan akun biaya lain-lain dan akun rugi lain-lain pada tahun 2007, sedangkan pada tahun 2008 dan 2009 perusahaan hanya mencantumkan biaya lain-lain. Atas biaya tersebut perusahaan tidak dapat merinci isi dari biaya lain-lain dan rugi lain-lain tersebut (tidak memiiki daftar nominatif). Oleh karena itu harus dilakukan koreksi positif sebesar Rp. 54.351,00 dan Rp. 4.739.973,00 untuk tahun 2007, Rp. 18.737.890,00 untuk tahun 2008, dan Rp. 76.209.668,00 untuk tahun 2009.

\section{Pendapatan Lain-Lain}

Perusahaan mengakui adanya pendapatan lain-lain pada laporan laba rugi, akan tetapi tidak dapat merinci asal (nature) dari pendapatan lain-lain tersebut. Oleh karena itu atas pendapatan lain lain tersebut harus dilakukan koreksi fiskal negatif sebesar Rp. 160.000.000,00 untuk tahun 2007, Rp. 17.085.512,00 untuk tahun 2008, dan Rp. 138.143,00 untuk tahun 2009.

\section{Pendapatan Jasa Giro Bank}

Perusahaan harus melakukan koreksi fiskal negatif atas jasa giro yang diterimanya. Berdasarkan PP 131 Tahun 2000 dan Keputusan Menteri Keuangan No. 51/KMK.04/2000 menyatakan bahwa atas jasa giro dan bunga deposito merupakan penghasilan yang dikenakan PPh Final Pasal 4 ayat 2. Dengan demikian perusahaan harus mengkoreksi pendapatan ini karena sudah dikenakan pajak final. Besarnya koreksi yang dilakukan adalah sebesar Rp. 92.881.564,00 untuk tahun 2007, Rp. 114.192.923,00 untuk tahun 2008, dan Rp. 143.075.484,00 untuk tahun 2009.

\section{Biaya Pajak Bunga}

Biaya bunga pajak merupakan biaya yang dikenakan atas pendapatan jasa giro yang sudah dikenakan $\mathrm{PPh}$ final. Oleh karena itu biaya pajak atas pendapatan jasa giro tersebut tidak diperbolehkan untuk dijadikan biaya oleh perusahaan. Dengan demikian perusahaan harus melakukan koreksi fiskal positif sebesar 20\% dari pendapatan bunga (pendapatan jasa giro x tarif PPh final 20\%) sesuai dengan Keputusan Menteri Keuangan No. 51/KMK/2001. Besarnya koreksi yang harus dilakukan adalah sebesar: 


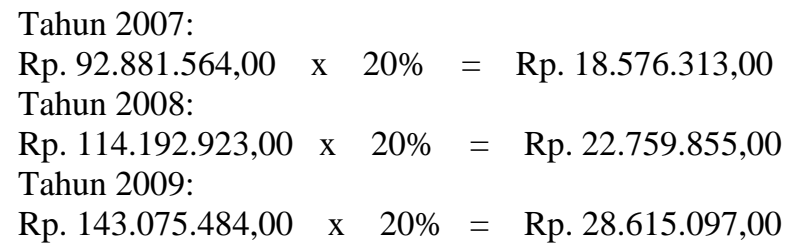

\section{Biaya Pajak PPN DN 2007}

Biaya pajak PPN masukan yang dibiayakan oleh perusahaan harus dikoreksi fiskal positif karena tidak didapatkan bukti atas pembayaran PPN tersebut dan tidak dapat diidentifikasi apakah pembayaran PPN itu terkait dengan kegiatan perusahaan untuk mendapatkan, menagih, dan memelihara penghasilannya. Hal tersebut diatur dalam SE-01/PJ./1991 dan PP No. 138 Tahun 2000 mengenai pajak masukan yang tidak dapat dikreditkan dan pembebanannya sebagai biaya perusahaan.

\section{Biaya Denda Pajak}

Perusahaan harus melakukan koreksi positif terhadap biaya denda pajak. Koreksi tersebut dilakukan berdasarkan UU PPh Pasal 9 ayat 1 (k) yaitu sanksi administrasi berupa bunga, denda, dan kenaikan serta sanksi pidana berupa denda yang berkenaan dengan pelaksanaan perundang-undangan di bidang perpajakan tidak diperkenankan dijadikan biaya untuk menentukan besarnya penghasilan kena pajak. Besarnya koreksi yang harus dilakukan adalah sebesar Rp. 5.352.523,00 untuk tahun 2007 dan Rp. 28.338.708,00 untuk tahun 2009. Sedangkan untuk tahun 2008, penulis tidak menemukan adanya biaya denda pajak.

\section{Perencanaan Pajak yang Diusulkan Penulis}

Mengingat adanya perbedaan antara perlakuan akuntansi secara komersial dengan perlakuan akuntansi menurut peraturan perpajakan, maka sebaiknya perusahaan dalam menentukan besarnya pajak penghasilan terhutang tidak hanya mengandalkan laporan keuangan komersial saja. Seharusnya perusahaan membuat laporan keuangan fiskal yang sudah melalui tahap koreksi fiskal yang didasarkan pada Undang-Undang perpajakan agar dapat dilakukan perencanaan pajak yang tepat dan efektif. Selama ini FA Trico Paint Factory belum memiliki karyawan yang benar-benar menguasai dan memahami perpajakan. Sehingga yang menangani masalah perpajakan sekarang ini hanya staf akuntansi yang tidak memiliki keahlian khusus di bidang perpajakan. Sebaiknya untuk meningkatkan kualitas pelaporan perpajakan serta tetap menjaga efisiensi pembayaran pajak yang diperlukan suatu perencanaan yang tepat, maka perusahaan harus merekrut karyawan profesional yang ahli di bidang perpajakan atau menggunakan jasa profesional konsultan pajak.

Gaji yang dibayarkan kepada anggota sekutu yang selama ini dibiayakan oleh perusahaan seharusnya dikoreksi atau dialokasikan menjadi prive yang mengurangi modal perusahaan. Karena apabila tidak dilakukan koreksi maka perusahaan beresiko mendapatkan sanksi perpajakan jika terjadi pemeriksaan pajak. Karena berdasarkan UU PPh Pasal 9 ayat 1 (j) dengan jelas menyatakan bahwa gaji yang dibayarkan kepada anggota sekutu yang modalnya tidak terbagi atas saham tidak diperkenankan sebagai pengurang penghasilan bruto. Selama ini perusahaan menanggung PPh Pasal 21 atas penghasilan karyawannya yang menurut Undang-Undang perpajakan hal itu tidak diperkenankan sebagai pengurang penghasilan sesuai dengan UU PPh Pasal 9 ayat 1 (h). Perencanaan yang sebaiknya dilakukan oleh perusahaan adalah dengan memberikan tunjangan pajak kepada karyawan. Dengan adanya tunjangan pajak tersebut, biaya pajak PPh 21 yang selama ini dibayarkan oleh perusahaan bisa dijadikan biaya yang dapat mengurangi penghasilan bruto perusahaan. Di sisi lain karyawan memperoleh penghasilan yang lebih besar. 
Pada tahun 2008 perusahaan mengeluarkan biaya pengobatan kantor. Atas biaya ini perusahaan perlu mengkoreksi fiskal sebesar Rp. 7.889.250,00, karena biaya ini dianggap sebagai natura/kenikmatan yang diterima karyawan maka tidak bisa menjadi pengurang penghasilan bruto perusahaan sesuai dengan UU PPh Pasal 9 ayat 1 (e). Untuk itu perencanaan pajak yang seharusnya dilakukan oleh perusahaan adalah dengan mengganti biaya pengobatan menjadi tunjangan pengobatan bagi karyawannya. Bagi karyawan tunjangan ini bisa menjadi tambahan penghasilan (take home pay) dan bagi perusahaan bisa menjadi pengurang penghasilan bruto (deductable expense).

Dalam menggunakan jasa pihak ketiga, perusahaan tidak pernah melakukan pemotongan PPh 23, seperti jasa pemeliharaan kendaraan, pemeliharaan peralatan kantor, pemeliharaan gedung kantor, serta jasa perizinan yang digunakan perusahaan di tahun 2008 dan jasa akuntansi yang baru digunakan pada tahun 2009. Pada prinsipnya, perusahaan sebagai wajib pajak badan berkewajiban melakukan pemotongan pajak atas withholding tax tersebut. Perencanaan yang dapat dilakukan perusahaan adalah melakukan pemotongan PPh 23 dengan cara memberikan tunjangan dengan metode gross up. Dengan metode ini maka perusahaan harus menggross up besarnya penghasilan atas jasa terlebih dahulu kemudian dari hasil penghasilan jasa setelah di gross up, dikalikan dengan tarif tunjangan pajak. Tarif tunjangan dengan metode gross up disesuaikan dengan Peraturan Direktur Jenderal Pajak No. PER70/PJ/2007 yang mengatur mengenai jenis jasa lain dan perkiraan penghasilan neto atas jasa tehnik, jasa manajemen, jasa konstruksi, jasa konsultan dan jasa lain yang atas imbalannya dipotong pajak penghasilan sebagaimana dimaksud dalam Pasal 23 UU PPh.

Perusahaan harus membuat daftar nominatif untuk biaya entertainment dan biaya lain-lain agar biaya-biaya tersbut tidak dianggap fiktif sehingga bisa dibiayakan oleh perusahaan untuk mengurangi penghasilan bruto. Daftar nominatif harus dibuat secara lengkap atas setiap transaksi yang terjadi dan dilampirkan dalam SPT Tahunan PPh sesuai dengan SE-27/PJ.22/1986.

Biaya sumbangan yang dikeluarkan oleh perusahaan tidak boleh dijadikan pengurang penghasilan bruto, karena sumbangan tidak berhubungan langsung dengan kegiatan usaha perusahaan. Perencanaan yang dapat dilakukan perusahaan atas biaya sumbangan ini agar dapat dibiayakan adalah dengan memberikan sumbangan kepada pihak - pihak yang diatur dalam SE-33/PJ.421/1996 yaitu sumbangan untuk beasiswa dalam rangka GNOTA dan Peraturan Menteri Keuangan No. 609/KMK03/2004 yaitu sumbangan untuk korban bencana alam yang dikategorikan sebagai bencana nasional oleh pemerintah seperti bencana tsunami di Aceh.

Pada laporan laba rugi terdapat pendapatan bunga yang diperoleh perusahaan atas jasa giro. Dimana atas penghasilan tersebut sudah dikenakan pajak yang bersifat final sebesar $20 \%$. Seharusnya penghasilan ini harus dikoreksi negatif karena jika tidak dikoreksi maka perusahaan akan terkena pajak dua kali (ganda) yaitu PPh Final Pasal 4 ayat 2 atas pendapatan bunga dan PPh Pasal 17 ayat 1 atas wajib pajak badan. Begitu juga untuk biaya pajak atas pendapatan bunga tersebut juga harus dikoreksi positif. Hal ini dilakukan agar perusahaan terhindar dari sanksi pajak karena melakukan kesalahan dalam pengisian SPT.

Dalam menyetorkan dan melaporkan pajak sebaiknya perusahaan melakukannya secara benar dan tidak terlambat. Karena di tahun 2007 dan 2009 terdapat sanksi berupa denda yang merugikan perusahaan. Menyetor dan melaporkan pajak secara benar dan tepat waktu merupakan salah satu tax planning agar terhindar dari sanksi perpajakan baik sanksi administratif berupa denda atau bunga maupun sanksi pidana. Sehingga penghematan pajak yang diperoleh perusahaan setelah perencanaan pajak adalah seperti pada Gambar 1-3. 
Perhitungan pajak terhutang Tahun 2007

\begin{tabular}{|c|c|c|c|c|c|c|c|}
\hline \multirow{2}{*}{$\begin{array}{r}\text { Keterangan } \\
\text { Laba Sebelum Pajak }\end{array}$} & \multicolumn{2}{|c|}{ Sebelum Tax Planning } & \multicolumn{2}{|c|}{ Setelah Tax Planning } & \multicolumn{2}{|c|}{ Penghematan (Rp) } & \multirow{2}{*}{$\begin{array}{c}\text { Penghematan (\%) } \\
8.03 \%\end{array}$} \\
\hline & $\mathbf{R p}$ & $1,097,809,471.00$ & $\mathbf{R p}$ & $1,009,617,907.00$ & $\mathbf{R p}$ & $88,191,564.00$ & \\
\hline \multicolumn{8}{|l|}{ PPh Badan } \\
\hline $10 \%$ x Rp. $50.000 .000,00$ & $\mathrm{Rp}$ & $5,000,000.00$ & $\mathrm{Rp}$ & $5,000,000.00$ & & & \\
\hline $15 \%$ x Rp. $50.000 .000,00$ & $\mathrm{Rp}$ & $7,500,000.00$ & $\mathrm{Rp}$ & $7,500,000.00$ & & & \\
\hline $30 \%$ x Rp. $997.809 .471,00$ & $\mathrm{Rp}$ & $299,342,841.30$ & & & & & \\
\hline $30 \%$ x Rp. $909.617 .907,00$ & & & $\mathrm{Rp}$ & $272,885,372.10$ & & & \\
\hline Total Pajak Terhutang & $\mathbf{R p}$ & $311,842,841.30$ & $\mathbf{R p}$ & $285,385,372.10$ & $\mathbf{R p}$ & $26,457,469.20$ & $8.48 \%$ \\
\hline Angsuran PPh & $\mathbf{R}_{\mathbf{p}}$ & $25,986,903.44$ & $\mathbf{R p}_{\mathbf{p}}$ & $23,782,114.34$ & & & \\
\hline
\end{tabular}

Gambar 1 Perhitungan Pajak Terhutang Tahun 2007

Perhitungan pajak terhutang Tahun 2008

\begin{tabular}{|c|c|c|c|c|c|c|c|}
\hline \multirow{2}{*}{$\begin{array}{c}\text { Keterangan } \\
\text { Laba Sebelum Pajak }\end{array}$} & \multicolumn{2}{|c|}{ Sebelum Tax Planning } & \multicolumn{2}{|c|}{ Setelah Tax Planning } & \multicolumn{2}{|c|}{ Penghematan (Rp) } & \multirow{2}{*}{$\begin{array}{c}\text { Penghematan (\%) } \\
9.12 \%\end{array}$} \\
\hline & Rp & $1,344,173,436.50$ & Rp & $1,221,518,164.16$ & Rp & $122,655,272.34$ & \\
\hline \multicolumn{8}{|l|}{ PPh Badan } \\
\hline $15 \%$ x Rp. $50.000 .000,00$ & $\mathrm{Rp}$ & $7,500,000.00$ & $\mathrm{Rp}$ & $7,500,000.00$ & & & \\
\hline $30 \%$ x Rp. $997.809 .471,00$ & $\mathrm{Rp}$ & $373,252,030.95$ & & & & & \\
\hline $30 \%$ x Rp. $909.617 .907,00$ & & & $\mathrm{Rp}$ & $336,455,449.25$ & & & \\
\hline Total Pajak Terhutang & Rp & $385,752,030.95$ & Rp & $348,955,449.25$ & $\mathbf{R p}$ & $36,796,581.70$ & $9.54 \%$ \\
\hline Angsuran PPh & Rp & $32,146,002.58$ & Rp & $29,079,620.77$ & & & \\
\hline
\end{tabular}

Gambar 2 Perhitungan Pajak Terhutang Tahun 2008

Perhitungan pajak terhutang Tahun 2009

(Dalam Rupiah Penuh)

\begin{tabular}{|c|c|c|c|c|}
\hline Keterangan & $\begin{array}{l}\text { Sebelum Tax } \\
\text { Pianning }\end{array}$ & $\begin{array}{c}\text { Setelah Tax } \\
\text { Planning }\end{array}$ & $\begin{array}{c}\text { Penghematan } \\
\text { (Rp) }\end{array}$ & $\begin{array}{c}\text { Penghematan } \\
(\%)\end{array}$ \\
\hline Laba Sebelum Pajak & $1,450,929,911.00$ & $1,280,458,027,04$ & $170,471,883.96$ & $11.75 \%$ \\
\hline \multicolumn{5}{|l|}{ PPh Badan } \\
\hline \multicolumn{5}{|l|}{ PKP Fasilitas } \\
\hline (Rp. 4,8 Milyar/Rp. 39.851.765.010,00) x Rp. $1.450 .929 .911,00$ & $174,759,225.12$ & & & \\
\hline (Rp. 4,8 Milyar/Rp. 39.851.765.010,00) x Rp. $1.280 .458 .027,04$ & & $154,226,507.36$ & & \\
\hline \multicolumn{5}{|l|}{ PKP Non F asilitas } \\
\hline (Rp. 1.450.929.911,00 - Rp. 174.759.225.12) & $1,276,170,685.88$ & & & \\
\hline (Rp. 1.280.458.027,04 - Rp. 154.226.507,36) & & $1,126,231,519.68$ & & \\
\hline \multicolumn{5}{|l|}{ Pajak Terhutang } \\
\hline \multicolumn{5}{|l|}{ PPh Terhutang Dengan F asilitas } \\
\hline $14 \%$ x Rp. $174.759 .225,12$ & $24,466,291.52$ & & & \\
\hline $14 \%$ x Rp. $154.226 .507,36$ & & $21,591,711.03$ & & \\
\hline \multicolumn{5}{|l|}{ PPh Terhutang Non Fasilitas } \\
\hline $28 \% \times$ xp. $1.276 .170 .685,88$ & $357,327,792.05$ & & & \\
\hline $28 \% \times$ xp. $1.126 .231 .519,68$ & & $315,344,825.51$ & & \\
\hline Total Pajak Terhutang & $381,794,083.56$ & $336,936,536.54$ & $44,857,547,02$ & $11.75 \%$ \\
\hline Angsuran PPh & $31,816,173,63$ & $28,078,044.71$ & & \\
\hline
\end{tabular}

Gambar 3 Perhitungan Pajak Terhutang Tahun 2009 


\section{PENUTUP}

\section{Simpulan}

Berdasarkan perhitungan dan perencanaan pajak yang sudah penulis lakukan, maka dapat dihasilkan simpulan bahwa perusahaan belum melakukan perencanaan pajak yang tepat dan efektif. Perusahaan belum memiliki pemahaman yang baik dalam membedakan antara laporan keuangan komersial dengan laporan keuangan fiskal. Hal ini dapat dijelaskan dengan adanya koreksi fiskal yang masih harus dilakukan oleh perusahaan karena terdapat pos-pos pendapatan dan biaya yang perlakuannya belum sesuai dengan ketentuan perpajakan yang berlaku. Perusahaan selama ini masih menanggung PPh Pasal 21 karyawannya, hal ini merugikan perusahaan karena PPh Pasal 21 yang ditanggung perusahaan tidak dapat dijadikan pengurang penghasilan bruto perusahaan (non-deductible expenses). Dalam transaksi pemanfaatan jasa pihak ketiga, perusahaan tidak melakukan pemotongan $\mathrm{PPh}$ Pasal 23 yang merupakan kewajiban perusahaan sebagai pemotong withholding tax. Sesuai dengan Pasal 13 ayat 2 dan 3 Undang-Undang No. 28 Tahun 2007 tentang Ketentuan Umum dan Tata Cara Perpajakan, jika berdasarkan hasil pemeriksaan perusahaan dengan sengaja tidak memotong PPh Pasal 23 maka akan dikenakan sanksi administrasi berupa bunga yang besarnya 2\% per bulan selama 24 bulan sampai dengan sanksi kenaikan sebesar 100\% dari PPh yang tidak atau kurang dipotong.

Perusahaan tidak membuatkan daftar nominatif atas biaya yang berkaitan dengan entertainment dan biaya lain-lain sehingga tidak dapat diperhitungkan sebagai pengurang penghasilan bruto perusahaan. Perusahaan belum melakukan koreksi negatif terhadap penghasilan bunga dan koreksi positif terhadap biaya pajak atas bunga yang telah dikenakan PPh Final Pasal 4 ayat 2 sebesar $20 \%$. Seharusnya dalam merencanakan pajaknya, perusahaan dapat mengganti biaya yang berkaitan dengan karyawannya seperti biaya pajak PPh 21 dan biaya pengobatan dengan cara menjadikan biaya tersebut sebagai tunjangan yang menambah penghasilan karyawan agar dapat dibiayakan sebagai pengurang penghasilan bruto. Perencanaan pajak atas pemotongan PPh Pasal 23 yang dilakukan terhadap pihak pemberi jasa adalah dengan menggunakan metode gross up. Metode ini digunakan agar biaya yang dibayarkan kepada pihak ketiga tersebut lebih besar sehingga biaya atas pembayaran jasa tersebut dapat lebih besar pula mengurangi penghasilan bruto perusahaan secara keseluruhan. Hal tersebut dilakukan mengingat lebih besarnya tarif $\mathrm{PPh}$ Badan perusahaan jika dibandingkan dengan PPh Pasal 23. Dari perencanaan pajak yang telah dilakukan berdasarkan Undang - Undang perpajakan yang berlaku, penghematan pajak yang dapat dihasilkan adalah sebesar 8,48\% atau Rp. 26.457.469,20 pada tahun 2007. Pada tahun 2008 dihasilkan penghematan sebesar 9,54\% atau Rp. 36.796.581,70. Dan pada tahun 2009 dapat dihasilkan penghematan sebesar 11,75\% atau Rp. 44.857.547,02. Jika perusahaan dapat menerima usulan perencanaan pajak ini, maka diperkirakan perusahaan dapat menghemat pembayaran pajaknya sebesar rata - rata $10 \%$ per tahun.

\section{Saran}

Beberapa saran yang diusulkan dalam hubungannya dengan perencanaan pajak di masa yang akan datang, yaitu: (1) perusahaan harus terus mengikuti perkembangan peraturan perpajakan, yaitu dengan cara menjadi anggota berbagai situs perpajakan agar dapat mengup date informasi terbaru, membaca peraturan terbaru, serta mengikuti seminar-seminar perpajakan yang dapat menambah informasi perpajakan. Hal ini dilakukan terutama untuk karyawan bagian keuangan perusahaan. (2) Perusahaan sebaiknya mengganti cara perhitungan PPh Pasal 21 yang selama ini ditanggung oleh perusahaan dengan tunjangan pajak. Dengan dijadikan tunjangan pajak, maka tunjangan pajak ini dapat dijadikan pengurang penghasilan bruto perusahaan. Sedangkan bagi karyawan tunjangan pajak tersebut dapat menambah penghasilannya. (3) Perusahaan sebaiknya memotong PPh Pasal 23 atas setiap penggunaan jasa pihak ketiga seperti jasa perizinan, konsultan, dan pemeliharaan. Perusahaan juga harus melaporkan, menyetorkan, dan melampirkannya pada SPT tahunan perusahaan. (4) Dalam 
melakukan pemotongan PPh Pasal 23 sebaiknya perusahaan menggunakan metode gross up. (5) Sebaiknya perusahaan membuatkan daftar nominatif dan melampirkannya pada SPT perusahaan atas biaya entertainment agar dapat dijadikan deductable expense. (6) Sebaiknya perusahaan melakukan pembetulan terhadap SPT yang telah dilaporkan karena adanya beberapa perubahan koreksi fiskal baik positif maupun negatif. Pembetulan ini dilakukan dalam rangka mencegah timbulnya sanksi administrasi baik bunga, denda, maupun sanksi pidana dikemudian hari.

\section{DAFTAR PUSTAKA}

Djuanda, \& Lubis, I. (2001). Pelaporan pajak penghasilan. Jakarta: Gramedia Pustaka Utama.

Gunadi. (2003). Akuntansi pajak sesuai dengan undang-undang pajak baru. Jakarta: Gramedia Widiasarana Indonesia.

Harnanto. (2001). Akuntansi perpajakan. Yogyakarta: Badan Penerbit Fakultas Ekonomi.

Suandy, E. (2003). Perencanaan pajak. Jakarta: Salemba Empat.

Undang-Undang Republik Indonesia. (2008). Undang-Undang Republik Indonesia Nomor 36 Tahun 2008 Tentang Perubahan Keempat Atas Undang-Undang Nomor 7 Tahun 1983 Tentang Pajak Penghasilan. Jakarta: Pustaka Yustisia.

Undang-Undang Republik Indonesia. (2000). Undang-Undang Republik Indonesia Nomor 17 Tahun 2000 .

Zain, M. (2005). Manajemen perpajakan. Jakarta: Salemba Empat. 